\title{
Assembly of fully substituted triazolochromenes via a novel multicomponent reaction or mechanochemical synthesis
}

\author{
Robby Vroemans ${ }^{1}$, Yenthel Verhaegen ${ }^{1}$, My Tran Thi Dieu ${ }^{1,2}$ and Wim Dehaen ${ }^{* 1}$
}

\author{
Full Research Paper \\ Address: \\ ${ }^{1}$ Molecular Design and Synthesis, Department of Chemistry, KU \\ Leuven, Celestijnenlaan 200F, 3001 Leuven, Belgium and ${ }^{2}$ The \\ University of Danang, University of Science and Education, 459 Ton \\ Duc Thang, Lien Chieu, Danang, Vietnam \\ Email: \\ Wim Dehaen* - wim.dehaen@chem.kuleuven.be \\ * Corresponding author \\ Keywords: \\ ball milling; multicomponent reaction; 3-nitro-2H-chromene; one-pot \\ synthesis; 1,2,3-triazole
}

Beilstein J. Org. Chem. 2018, 14, 2689-2697. doi:10.3762/bjoc. 14.246

Received: 24 July 2018

Accepted: 08 October 2018

Published: 22 October 2018

Associate Editor: T. J. J. Müller

(C) 2018 Vroemans et al.; licensee Beilstein-Institut. License and terms: see end of document.

\begin{abstract}
A new metal-free one-pot three-component procedure towards fully substituted triazolochromenes has been developed, starting from commercially available materials. Salicylaldehydes and nitroalkenes were reacted under solvent-free conditions, followed by a 1,3-dipolar cycloaddition of the intermediate 3-nitro- $2 H$-chromenes with organic azides in a one-pot two-step sequence. The triazolochromenes were formed with complete regioselectivity and new biologically relevant structures were synthesized via extension of the developed procedure and via postfunctionalization. The mechanochemical synthesis was carried out for several salicylaldehydes and gave a clear improvement in the yield of the corresponding triazolochromenes and consequently showed to be a viable alternative for solid salicylaldehydes.
\end{abstract}

\section{Introduction}

Chromenes are important structural motifs and are omnipresent in nature and drugs for medicinal applications [1-4]. Vitamin E [5-8], arahypin-5 [9,10], THC and other cannabinoids [11-14] are only a few examples of biologically relevant chromenes. Hence, the search for new methodologies towards the rapid assembly of chromene analogs is of utmost importance for many researchers. In this regard, 3-nitrochromenes are easily available building blocks for chromene and chromane deriva- tives and are highly reactive due to the presence of the nitroalkene moiety, which enables them to undergo a high variety of reactions and functionalizations [15].

Combining the chromene core with the 1,2,3-triazole structural motif has led to some interesting new molecules [16-31]. Very recently, spiro-fused triazolochromenes were found to be active as antitubercular agents [32], indicating that the development of 
new triazolochromenes in a straightforward manner is still of major interest. Previously, $\mathrm{NH}$-triazolochromenes were synthesized starting from 3-nitrochromenes with sodium azide [16-22], via intramolecular cyclization of a diazomethane group and a nitrile [23], or via our recently reported $\mathrm{NH}$-triazole synthesis starting from 6-methoxyflavanone [24]. Furthermore, 1,4,5-trisubstituted 1,2,3-triazole annulated chromenes have been reported via an intramolecular arylation reaction of 1,2,3triazoles [25-31]. Yet, the developed methodologies for trisubstituted triazolochromenes generally lack a substituent on the 2-position, except for a sporadic methyl group which drastically lowers the yield and often the use of transition metals is needed [28]. The additional substituents on the chromene core and 1,2,3-triazole offer a lot of possibilities for further derivatization and optimization towards biologically relevant structures such as flavonoid structures.

Our group developed a Knoevenagel-assisted three-component reaction of (protected) salicylaldehyde, ethyl nitroacetate and organic azides, in which the synthesis of both triazolocoumarin regioisomers was accomplished [33]. Interestingly, the expected regioisomer was not observed in the case of the in situ formed 3-nitrocoumarins. Hence, in our continued exploration towards novel multicomponent reactions for the assembly of triazole-fused (hetero)cycles [24,33-42], we opted to develop a new one-pot two-step three-component reaction starting from salicylaldehydes, nitroalkenes and organic azides, without isolation of the intermediate 3-nitrochromenes, in a regioselective manner and without the use of metals. Salicylaldehydes with a high melting point or low solubility proved difficult to convert to the intermediate 3-nitrochromene derivatives [15]. In this regard, applying mechanochemistry has been proven previously to be a viable alternative [43]. To the best of our knowledge, both the development of a metal-free sequential one-pot three-component reaction and the mechanochemically assisted 3-nitrochromene synthesis towards fully substituted tria- zolochromenes, without the isolation of the intermediate 3-nitrochromenes, have not been reported until now.

\section{Results and Discussion}

To prove the plausibility of the one-pot three-component reaction, we commenced our trials with the synthesis and isolation of 3-nitro-2H-chromene (3) as reported in the literature [15], followed by the 1,3-dipolar cycloaddition of the nitroalkene moiety with organic azides. We based the 1,3-dipolar cycloaddition reaction on the synthesis of $\mathrm{NH}$-triazoles by Guan et al. using $p$-toluenesulfonic acid as the catalyst in DMF [19], but with benzyl azide (4a) instead of sodium azide (Scheme 1). Our initial test gave a promising result, since after a reaction time of five days for the cycloaddition step the desired product 5a was obtained in $67 \%$ yield, together with an oxidized ring opened side product $\mathbf{6}$ in $20 \%$ yield. The overall yield of $\mathbf{5 a}$ after two steps was $48 \%$, considering that the 3-nitro- $2 H$-chromene (3) was obtained in a yield of $71 \%$.

We continued our studies by verifying the obtained regiochemistry, in which we synthesized the different regioisomers 5a, 10 and 11 via different pathways (Scheme 2). The regiospecific syntheses [36] of compounds 5a and $\mathbf{1 1}$ were accomplished by triazolization of the corresponding flavanone 7 and 2-phenylchroman-3-one (8), respectively. As anticipated, these methods furnished both regioisomers in poor yields since the chromanones $\mathbf{7}$ and $\mathbf{8}$ are known to be unstable under the triazolization conditions [36]. Hence, no further attempts were made to improve these yields. Additionally, $\mathrm{NH}$-triazole 9 could be alkylated using benzyl bromide and potassium carbonate in acetone providing a mixture of alkylated triazolochromenes $\mathbf{5 a}$, $\mathbf{1 0}$ and 11. The polarity of the 2-alkylated triazolochromene $\mathbf{1 0}$ is significantly different than the other two which were obtained as an inseparable mixture of both regioisomers 5a and $\mathbf{1 1}$ in a 1:3 ratio. Comparing the ${ }^{1} \mathrm{H}$ NMR spectra (see Supporting Information File 1, Figure S1 for NMR comparison), we can<smiles>O=Cc1ccccc1O</smiles>

$1 \mathrm{a}$<smiles>N/C=C/c1ccccc1</smiles>

2a $40{ }^{\circ} \mathrm{C}, 1.5 \mathrm{~h}$<smiles>O=[N+]([O-])C1=Cc2ccccc2OC1c1ccccc1</smiles>

$3(71 \%)$<smiles>N#CC1=CC=CC=[C+]1</smiles>

$4 a$<smiles>O=C(c1ccccc1)c1nnn(Cc2ccccc2)c1-c1ccccc1O</smiles> 
<smiles>O=[N+]([O-])C1=Cc2ccccc2OC1c1ccccc1</smiles><smiles>c1ccc(Cn2nnc3c2-c2ccccc2OC3c2ccccc2)cc1</smiles>
$5 a$<smiles>O=C1CC(c2ccccc2)Oc2ccccc21</smiles>
7<smiles>c1ccc(Cn2nc3c(n2)C(c2ccccc2)Oc2ccccc2-3)cc1</smiles>

10

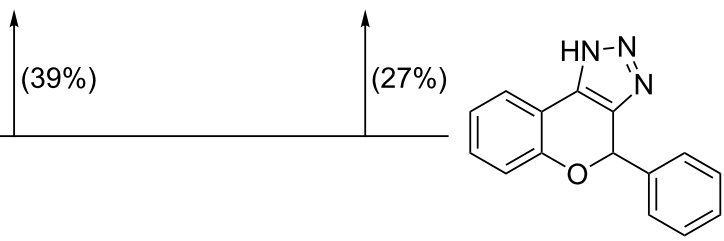

9

Scheme 2: Reaction pathways leading to the different regioisomers.

make unambiguous conclusions about the regiochemistry of the synthesized compounds 5a, 10 and $\mathbf{1 1}$ (Scheme 2). As the product contains a stereocenter, there is a possibility to see diastereotopic splitting of the benzylic protons. In the spectrum of the obtained product 5a starting from 3-nitro- $2 \mathrm{H}$-chromene and flavanone, this splitting is not observed ( $\mathrm{A}_{2}$ pattern). The benzylic peak of the 2-alkylated product $\mathbf{1 0}$ shows an $\mathrm{AB}$ splitting pattern and the third regioisomer 11 shows a substantial AX splitting pattern. This striking difference can be rationalized in function of the proximity of the stereocenter to the diastereotopic protons. Further proof was provided by characterization of side product 6 [44], which is formed during the reaction by oxidation and ring-opening of triazolochromene 5a (Scheme 1). All these observations confirm the expected regioselectivity in the formation of triazolochromene 5a via 3-nitro$2 H$-chromene (3).

Next, the two-step synthesis was converted into a one-pot twostep synthesis, circumventing the need for isolating the intermediate 3-nitro- $2 H$-chromene (3), which would greatly facilitate the purification of the overall reaction since the 3-nitro- $2 \mathrm{H}$ chromenes and their starting materials show similar retention factors. Since the triazolochromenes $\mathbf{5}$ are showing much lower retention factors, the one-pot synthesis would display a great improvement in the labor intensiveness both for the purification steps and reaction set-up. The reaction was further optimized using salicylaldehyde (1a), $\beta$-nitrostyrene (2a) and benzyl azide (3a) as model substrates (see Supporting Information File 1, pages S4-S8 for full description of the optimization study). The optimized conditions for the one-pot three-component reaction were determined to be 1 equivalent nitroalkene, 1.2 equivalents of salicylaldehyde and 0.1 equivalents of $\mathrm{DABCO}$ as catalyst in the first step at $40{ }^{\circ} \mathrm{C}$, and 2 equivalents of benzyl azide, 2 equivalents of acetic acid, 0.3 equivalents of BHT as antioxidant, $4 \AA \mathrm{MS}$ and DMF under argon atmosphere at $120^{\circ} \mathrm{C}$ in the second step. Crude NMR analysis of the reaction mixture under optimized conditions showed solely regioisomer 5a, which was obtained in 54\% yield after chromatographic purification. Additionally, the optimized conditions gave improved yields compared to the two-step synthesis and circumvented the formation of oxidized side product 6 . As variation of the substituents on the three different starting materials is necessary to obtain a diverse library, there is one main limitation to overcome. The first step of the reaction relies on the fluidity of salicylaldehyde (1a) to liquefy the reaction mixture. Salicylaldehyde analogs $1 \mathbf{c}-\mathbf{f}$ are solids at $40{ }^{\circ} \mathrm{C}$ and hence, to overcome this problem, some slight modifications from the optimized conditions were done (see Supporting Information File 1, pages S6 and S7 for more detailed description of the performed experiments for compound 5a). Eventually, the use of two equivalents of triethylamine was needed but the overall yield of 5a was still lower as it only reached 38\%.

With the obtained optimized conditions and proof of regioselectivity in hand, further investigation towards the generality of this three-component reaction was carried out by varying the substrate scope (Figure 1). We first studied a range of salicylaldehydes $\mathbf{1 a}-\mathbf{f}$, from which $\mathbf{5 a}$ and $\mathbf{5 b}$ were obtained in 
1. 1,2 , DABCO (0.1 equiv), $40^{\circ} \mathrm{C}, 1.5 \mathrm{~h}$

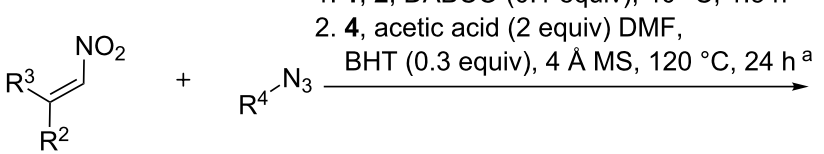

4a, $\mathrm{R}^{4}=\mathrm{Bn}$

4b, $\mathrm{R}^{4}=\mathrm{CH}_{2} \mathrm{CH}(\mathrm{OMe})_{2}$

4c, $\mathrm{R}^{4}=\mathrm{CH}_{2} \mathrm{COOEt}$

4d, $\mathrm{R}^{4}=n-\mathrm{C}_{12} \mathrm{H}_{25}$

$4 \mathrm{e}, \mathrm{R}^{4}=3,4,5-\mathrm{MeO}-\mathrm{Ph}$

4f, $\mathrm{R}^{4}=\mathrm{Ph}$

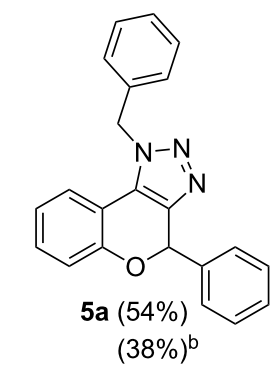

$(38 \%)^{b}$<smiles>Brc1ccc2c(c1)-c1c(nnn1Cc1ccccc1)C(c1ccccc1)O2</smiles>

5e $(27 \%)^{b}$<smiles>COc1ccc2c(c1)-c1c(nnn1Cc1ccccc1)C(c1ccccc1)O2</smiles>

5b $(60 \%)^{c}$<smiles>Clc1cc(Cl)c2c(c1)-c1c(nnn1Cc1ccccc1)C(c1ccccc1)O2</smiles>

5f $(14 \%)^{b}$<smiles>CC1(C)Oc2ccccc2-c2c1nnn2Cc1ccccc1</smiles>

$5 i(22 \%)^{9}$<smiles>COC(Cn1nnc2c1-c1ccccc1OC2c1ccccc1)OC</smiles>

5j (48\%)<smiles>COc1cccc2c1-c1c(nnn1Cc1ccccc1)C(c1ccccc1)O2</smiles><smiles>COC(=O)c1ccc2c(c1)-c1c(nnn1Cc1ccccc1)C(c1ccccc1)O2</smiles>

5d $(11 \%)^{b, e}$<smiles>[Y1][Y1]1ccc2c(c1)-c1c(nnn1[R])C([R])([R])O2</smiles>

5a-o<smiles>COc1cc(C2Oc3ccccc3-c3c2nnn3Cc2ccccc2)cc(OC)c1OC</smiles><smiles>c1ccc(Cn2nnc3c2-c2ccccc2OC3c2ccc3c(c2)OCO3)cc1</smiles>

$5 \mathrm{~h}(9 \%)^{\mathrm{e}}$<smiles>CCCCCCCCCCCCn1nnc2c1-c1ccccc1OC2c1ccccc1</smiles>

5k (30\%)<smiles>COc1cc(-n2nnc3c2-c2ccccc2OC3c2ccccc2)cc(OC)c1OC</smiles><smiles>c1ccc(C2Oc3ccccc3-c3c2nnn3-c2ccccc2)cc1</smiles>

5n $(38 \%)^{i}$<smiles>O=[N+]([O-])c1ccc(-n2nnc3c2-c2ccccc2OC3c2ccccc2)cc1</smiles>

Figure 1: Scope with respect to various salicylaldehydes 1a-f, nitroalkenes $\mathbf{2 a - d}$ and organic azides $\mathbf{4 a - g}$. ${ }^{\text {Reaction }}$ conditions for two-step one-pot procedure: 1. 1 (1.2 equiv), 2 (1 equiv), DABCO ( 0.1 equiv), $1.5 \mathrm{~h}, 40^{\circ} \mathrm{C} ; 2.4$ (2 equiv), acetic acid (2 equiv), BHT (0.3 equiv), $4 \AA \mathrm{MS}$ ( $50 \mathrm{mg}$ ), DMF $(0.1 \mathrm{~mL}), 24 \mathrm{~h}, 120^{\circ} \mathrm{C}$. b Reaction conditions for two-step one-pot procedure with solid salicylaldehydes: 1.1 (1.2 equiv), 2 (1 equiv), triethylamine (2 equiv), $1.5 \mathrm{~h}, 40^{\circ} \mathrm{C} ; 2$. Same as for ${ }^{\mathrm{a}}$. ${ }^{\mathrm{C}}$ Reaction time for the second step: $27 \mathrm{~h}$. ${ }^{\mathrm{d}}$ Reaction time for the first step: $24 \mathrm{~h}$; second step: $29 \mathrm{~h}$. ${ }^{\mathrm{e}}$ Reaction

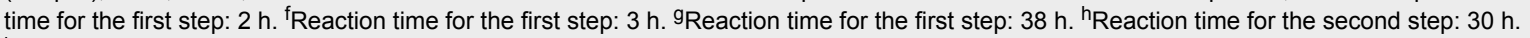

iReaction time for the second step: $45 \mathrm{~h}$. 
the best yields since salicylaldehydes $\mathbf{1 a}$ and $\mathbf{1 b}$ are liquids. As mentioned earlier, the altered conditions for solid salicylaldehydes result in general in a decrease in yield. Yet, we were able to diversify towards electron-rich triazolochromenes $\mathbf{5 b}$ and $\mathbf{5 c}$ resulting in a drastic loss in yield for the more sterically hindered compound 5c. Furthermore, electron-deficient and halogenated analogs $\mathbf{5 d - f}$ were successfully synthesized. In a next series, we examined the substitution pattern on the nitroalkene part. Electron-rich substituents 3,4,5-trimethoxyphenyl and piperonyl were tolerated and furnished products $\mathbf{5 g}$ and $\mathbf{5 h}$, respectively. 2,2-Dimethyl-substituted derivative $\mathbf{5 i}$ was prepared from 2-methyl-1-nitroprop-1-ene (2d) and interestingly, 1,4-bis((E)-2-nitrovinyl)benzene (2e) furnished bischromenotriazole 5p in $26 \%$ yield (Scheme 3). Finally, the scope with respect to organic azides was investigated by performing reactions with alkyl and aryl azides $\mathbf{4 a - g}$. Electron-rich aliphatic azides produced products $\mathbf{5} \mathbf{j}-\mathbf{l}$ in moderate yields. Additionally, electron-rich and electron-deficient aromatic azides were explored, resulting in slightly lower yields and elongated reaction times in the cycloaddition step compared to aliphatic azides. Unfortunately, this reaction has encountered some limitations towards certain substrates (not shown). In the case of a strongly electron-withdrawing substituent on the nitroalkene part for (E)-1-nitro-4-(2-nitrovinyl)benzene and sterically hindered 2-hydroxy-1-naphthaldehyde, only the oxidized product analogous to 6 was observed. 2-Hydroxy-4-nitrobenzaldehyde and 2,6-dihydroxybenzaldehyde were unreactive in the cycloaddition reaction.

As previously mentioned, solid salicylaldehydes furnish triazolochromenes in diminished yields in the one-pot three-component reaction (Figure 1, compounds 5c-f). Hence, a mechanochemical two-step protocol was developed, since a report by Jia and Zhang et al. [43] previously showed that ball milling could be a convenient manner to produce 3-nitrochromenes. Because our first step is best performed sol- vent-free, we opted to try our own optimized solvent-free conditions for the in situ syntheses of 3-nitro- $2 H$-chromenes, followed by the 1,3-dipolar cycloaddition in a reaction vial. Despite being a two-pot procedure, purification of the intermediate 3-nitro- $2 H$-chromene is still circumvented. Hence, our initial trials were performed by using solid salicylaldehydes 1c-f (Figure 2), resulting in a significant increase in yield for triazolochromenes $\mathbf{5 c - f}$ compared to the one-pot procedure developed as described above (Figure 1). To compare the two methodologies, the two highest yielding liquid salicylaldehydes in the one-pot protocol, i.e., $\mathbf{1 a}$ and $\mathbf{1 b}$, were reacted in the twostep mechanochemically assisted reaction, giving rise to slightly lowered yields for compounds $\mathbf{5} \mathbf{a}$ and $\mathbf{5 b}$. Hence, the use of the ball milling procedure is advantageous when solid salicylaldehydes are used. Complementary to this the one-pot three-component reaction gave better results for liquid salicylaldehydes.

In order to show the utility of the developed methodologies towards possible drug discovery, the scalability of the reactions was explored (Scheme 4). Both developed methodologies easily led to gram scale syntheses without significant loss in yield, i.e., $50 \%$ and $40 \%$ for the one-pot three-component reaction and mechanochemical procedure, respectively.

Finally, the versatility of these novel methodologies was demonstrated by performing postfunctionalization strategies towards well-known biologically active analogs (Scheme 5) [3]. Pd-catalyzed reactions were effected on bromotriazolochromene 5e. The piperazin-1-ylchromenes have been identified to be potent inhibitors at the $5-\mathrm{HT}_{1 \mathrm{~A}}$ receptor and at the 5-HT transporter $[45,46]$. Thus, Buchwald-Hartwig amination of 1-phenylpiperazine and 5e furnishes piperazin-1-ylchromene 12 in 64\% yield. Furthermore, as highly methylated flavonoid derivatives [47] and 6-(3,5-dimethoxyphenyl)chromenes $[48,49]$ have been demonstrated to be potent anti-seizure drugs and anticancer agents, respectively, a Suzuki-Miyaura reaction<smiles>O=Cc1ccccc1O</smiles>

$1 a$

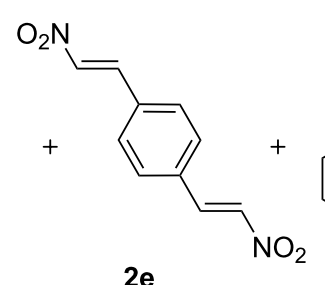

$2 e$

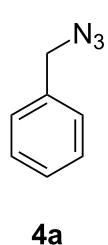

1. 1a, 2e, DABCO (0.1 equiv), $40^{\circ} \mathrm{C}, 3 \mathrm{~h}$

2. $4 a$, acetic acid (2 equiv), DMF $\mathrm{BHT}\left(0.3\right.$ equiv), $4 \AA \mathrm{MS}, 120^{\circ} \mathrm{C}, 24 \mathrm{~h}$ 
<smiles>[H][R1]1ccc(O)c(C=O)c1</smiles>

$1 a-f$<smiles>O=[N+]([O-])C=Cc1ccccc1</smiles>

$2 a$<smiles>N#Cc1ccccc1</smiles>

$4 a$
1. 1, 2a, DABCO (0.1 equiv), $30 \mathrm{~Hz}, 15 \mathrm{~min}$

2. $4 a$, acetic acid (2 equiv), DMF

$\mathrm{BHT}$ ( 0.3 equiv), $4 \AA \mathrm{MS}, 120^{\circ} \mathrm{C}, 24 \mathrm{~h}^{\mathrm{a}}$<smiles></smiles><smiles>COc1ccc2c(c1)-c1c(nnn1Cc1ccccc1)C(c1ccccc1)O2</smiles><smiles>[R1]Cc1ccc2c(c1)-c1nnn([R1])c1C([R])O2</smiles>

5a-f<smiles>COC(=O)c1ccc2c(c1)-c1c(nnn1Cc1ccccc1)C(c1ccccc1)O2</smiles>

$5 d(26 \%)^{b}$<smiles>Brc1ccc2c(c1)-c1c(nnn1Cc1ccccc1)C(c1ccccc1)O2</smiles>

5 e $(42 \%)$<smiles>COc1cccc2c1-c1c(nnn1Cc1ccccc1)C(c1ccccc1)O2</smiles><smiles>Clc1cc(Cl)c2c(c1)-c1c(nnn1Cc1ccccc1)C(c1ccccc1)O2</smiles>

$5 \mathbf{f}(30 \%)^{b}$

Figure 2: Generality of products obtained via the two-pot mechanochemical procedure, varying the salicylaldehydes $1 \mathrm{a}-\mathrm{f}$. ${ }^{\mathrm{a}}$ Reaction conditions for ball milling procedure, followed by 1,3-dipolar cycloaddition in a reaction vial: 1.1 (1.2 equiv), 2a (1 equiv), DABCO ( 0.1 equiv), 15 min, $30 \mathrm{~Hz}$; 2. $4 \mathrm{a}$ (2 equiv), acetic acid (2 equiv), BHT (0.3 equiv), $4 \AA \mathrm{MS}(50 \mathrm{mg}), \mathrm{DMF}(2 \mathrm{~mL}), 24 \mathrm{~h}, 120^{\circ} \mathrm{C}$. ${ }^{\circ}$ Reaction time for the first step: $2 \mathrm{~h}$. The overall isolated yields are given for 2 steps.<smiles>O=Cc1ccccc1O</smiles><smiles>[I-][I-]</smiles><smiles>O=[N+]([O-])/C=C/c1ccccc1</smiles>

$2 \mathrm{a}(1 \mathrm{~g})$<smiles>N#Cc1ccccc1</smiles>

$4 a$
1. 1a, 2a, $D A B C O$ (0.1 equiv), $40^{\circ} \mathrm{C}, 15 \mathrm{~min}$ 2. $4 a$, acetic acid (2 equiv), DMF BHT (0.3 equiv), $4 \AA \mathrm{MS}, 120^{\circ} \mathrm{C}, 24 \mathrm{~h}$<smiles>c1ccc(Cn2nnc3c2-c2ccccc2OC3c2ccccc2)cc1</smiles>

$5 a(50 \%, 1.13 \mathrm{~g})$<smiles>O=Cc1cc(Br)ccc1O</smiles>

$1 e$<smiles></smiles>

$2 \mathrm{a}(0.4 \mathrm{~g})$<smiles>N#CCc1ccccc1</smiles>

1. 1, 2a, DABCO (0.1 equiv), $30 \mathrm{~Hz}, 15 \mathrm{~min}$ 2. $4 a$, acetic acid (2 equiv), DMF $\mathrm{BHT}$ ( 0.3 equiv), $4 \AA \mathrm{MS}, 120^{\circ} \mathrm{C}, 24 \mathrm{~h}$<smiles>Brc1ccc2c(c1)-c1c(nnn1Cc1ccccc1)C(c1ccccc1)O2</smiles>

5e $(40 \%, 0.45 \mathrm{~g})$ 


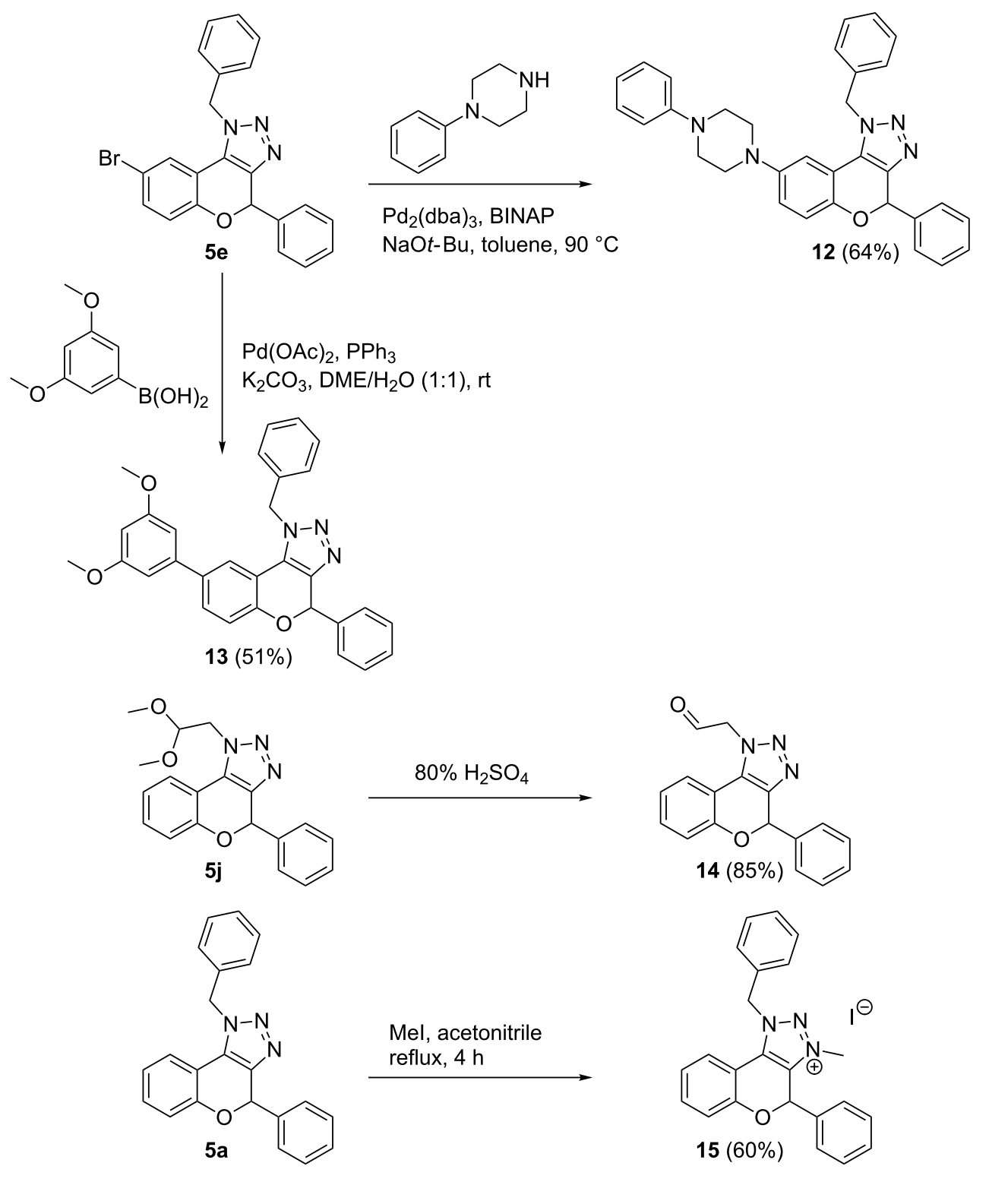

Scheme 5: Postfunctional transformations of triazolochromenes.

was performed yielding $\mathbf{1 3}$ in 51\% yield. Since aldehydes are interesting and versatile functional moieties for further derivatization, e.g., used in the synthesis of heterocyclic scaffolds $[33,34,50]$, several multicomponent reactions [40,51-53], etc., we wished to convert dimethyl acetal $\mathbf{5} \mathbf{j}$ into aldehyde appended triazolochromene $\mathbf{1 4}$ and at the same time examine the stability under strong acidic conditions. Aldehyde appended triazolochromene 14 was synthesized in $85 \%$ yield, providing the proof for their relative stability under acidic conditions. Finally, triazolium salt $\mathbf{1 5}$ was prepared from $\mathbf{5 a}$ in $60 \%$ yield and renders a polar triazolium annulated chromene.

\section{Conclusion}

We developed a sequential one-pot three-component reaction to access a variety of novel triazolochromenes avoiding the purification of intermediate 3-nitro- $2 H$-chromenes. The regiochemistry of the reaction was determined and proven, followed by a scope study using various salicylaldehydes, nitroalkenes and organic azides. Solid salicylaldehydes gave diminished yields in the one-pot three-component protocol, hence a two-step mechanochemical approach was developed offering higher yields and resulting in a complementary route for solid salicylaldehydes. The applicability of the newly developed protocols 
was shown by gram-scale syntheses and postfunctionalization reactions towards biologically relevant analogs. The biological data will be published in due course.

\section{Supporting Information}

Supporting information features the optimization studies, NMR comparison studies of the various regioisomers $\mathbf{5 a}$, 10 and 11, experimental details and copies of ${ }^{1} \mathrm{H}$ and ${ }^{13} \mathrm{C}$ NMR spectra of compounds $\mathbf{5 a}-\mathbf{p}$ and $\mathbf{1 0}-\mathbf{1 5}$.

\section{Supporting Information File 1 \\ Experimental part. \\ [https://www.beilstein-journals.org/bjoc/content/ supplementary/1860-5397-14-246-S1.pdf]}

\section{Acknowledgements}

We thank the KU Leuven for financial support. RV thanks the Fonds Wetenschappelijk Onderzoek - Vlaanderen (FWO) for a Ph.D. fellowship (1S13516N). Prof. Dr. Koen Binnemans is thanked for granting the permission to use the ball milling apparatus, Gerrit Van Haele and Karel Duerinckx are acknowledged for technical assistance of the used equipment. Mass spectrometry was made possible by the support of the Hercules Foundation of the Flemish Government (grant 20100225-7).

\section{ORCID ${ }^{\circledR}$ iDs}

Robby Vroemans - https://orcid.org/0000-0001-8641-6901 Yenthel Verhaegen - https://orcid.org/0000-0003-2937-5642 Wim Dehaen - https://orcid.org/0000-0002-9597-0629

\section{References}

1. Patil, S. A.; Patil, R.; Pfeffer, L. M.; Miller, D. D. Future Med. Chem. 2013, 5, 1647-1660. doi:10.4155/fmc. 13.126

2. Pratap, R.; Ram, V. J. Chem. Rev. 2014, 114, 10476-10526. doi:10.1021/cr500075s

3. Costa, M.; Dias, T. A.; Brito, A.; Proença, F. Eur. J. Med. Chem. 2016, 123, 487-507. doi:10.1016/j.ejmech.2016.07.057

4. Kumar, D.; Sharma, P.; Singh, H.; Nepali, K.; Gupta, G. K.; Jain, S. K.; Ntie-Kang, F. RSC Adv. 2017, 7, 36977-36999. doi:10.1039/C7RA05441F

5. Brigelius-Flohé, R.; Traber, M. G. FASEB J. 1999, 13, 1145-1155. doi:10.1096/fasebj.13.10.1145

6. Choe, E.; Min, D. B. Compr. Rev. Food Sci. Food Saf. 2009, 8, 345-358. doi:10.1111/j.1541-4337.2009.00085.x

7. Lu, D.; Yang, Y.; Li, Y.; Sun, C. Curr. Pharm. Anal. 2015, 11, 66-78. doi:10.2174/1573412910666140630170055

8. Péter, S.; Friedel, A.; Roos, F. F.; Wyss, A.; Eggersdorfer, M.; Hoffmann, K.; Weber, P. Int. J. Vitam. Nutr. Res. 2015, 85, 261-281. doi:10.1024/0300-9831/a000281

9. Sobolev, V. S.; Neff, S. A.; Gloer, J. B. J. Agric. Food Chem. 2009, 57, 62-68. doi:10.1021/jf802891v
10. Park, B. H.; Lee, H. J.; Lee, Y. R. J. Nat. Prod. 2011, 74, 644-649. doi:10.1021/np100696f

11. Hampson, A. J.; Grimaldi, M.; Axelrod, J.; Wink, D. Proc. Natl. Acad. Sci. U. S. A. 1998, 95, 8268-8273. doi:10.1073/pnas.95.14.8268

12. Ameri, A. Prog. Neurobiol. 1999, 58, 315-348. doi:10.1016/S0301-0082(98)00087-2

13. Croxford, J. L. Drugs 2003, 17, 179-202. doi:10.2165/00023210-200317030-00004

14. Reekie, T. A.; Scott, M. P.; Kassiou, M. Nat. Rev. Chem. 2017, 2, No. 0101. doi:10.1038/s41570-017-0101

15. Korotaev, V. Y.; Sosnovskikh, V. Y.; Barkov, A. Y. Russ. Chem. Rev. 2013, 82, 1081-1116. doi:10.1070/RC2013v082n12ABEH004370

16. Habib, P. M.; Raju, B. R.; Kavala, V.; Kuo, C.-W.; Yao, C.-F. Tetrahedron 2009, 65, 5799-5804. doi:10.1016/j.tet.2009.05.002

17. Das, B. C.; Mohapatra, S.; Campbell, P. D.; Nayak, S.; Mahalingam, S. M.; Evans, T. Tetrahedron Lett. 2010, 51, 2567-2570. doi:10.1016/j.tetlet.2010.02.143

18. Wang, T.; Hu, X.-C.; Huang, X.-J.; Li, X.-S.; Xie, J.-W. J. Braz. Chem. Soc. 2012, 23, 1119-1123. doi:10.1590/S0103-50532012000600017

19. Quan, X.-J.; Ren, Z.-H.; Wang, Y.-Y.; Guan, Z.-H. Org. Lett. 2014, 16, 5728-5731. doi:10.1021/ol5027975

20. Schwendt, G.; Glasnov, T. Monatsh. Chem. 2017, 148, 69-75. doi:10.1007/s00706-016-1885-5

21. Korotaev, V. Y.; Kutyashev, I. B.; Barkov, A. Y.; Sosnovskikh, V. Y. Chem. Heterocycl. Compd. 2017, 53, 597-603. doi:10.1007/s10593-017-2097-6

22. Sharma, P.; Kumar, N. P.; Senwar, K. R.; Forero-Doria, O.; Nachtigall, F. M.; Santos, L. S.; Shankaraiah, N. J. Braz. Chem. Soc. 2017, 28, 589-597. doi:10.21577/0103-5053.20160203

23. Mani, N. S.; Fitzgerald, A. E. J. Org. Chem. 2014, 79, 8889-8894. doi:10.1021/jo5013288

24. Thomas, J.; Jana, S.; Liekens, S.; Dehaen, W. Chem. Commun. 2016, 52, 9236-9239. doi:10.1039/C6CC03744E

25. Ackermann, L.; Jeyachandran, R.; Potukuchi, H. K.; Novák, P.; Büttner, L. Org. Lett. 2010, 12, 2056-2059. doi:10.1021/ol1005517

26. Reddy, M. N.; Swamy, K. C. K. Eur. J. Org. Chem. 2012, 2013-2022. doi:10.1002/ejoc.201101816

27. Schulman, J. M.; Friedman, A. A.; Panteleev, J.; Lautens, M. Chem. Commun. 2012, 48, 55-57. doi:10.1039/C1CC16110E

28. Jeyachandran, R.; Potukuchi, H. K.; Ackermann, L. Beilstein J. Org. Chem. 2012, 8, 1771-1777. doi:10.3762/bjoc.8.202

29. Chen, C.-Y.; Yang, C.-H.; Hu, W.-P.; Vandavasi, J. K.; Chung, M.-I.; Wang, J.-J. RSC Adv. 2013, 3, 2710-2719. doi:10.1039/c2ra22799a

30. Bai, S.-T.; Xiong, D.-C.; Niu, Y.; Wu, Y.-F.; Ye, X.-S. Tetrahedron 2015, 71, 4909-4919. doi:10.1016/j.tet.2015.05.108

31. Mondal, B.; Roy, B. Tetrahedron Lett. 2015, 56, 6123-6127. doi:10.1016/j.tetlet.2015.09.096

32. Ashok, D.; Chiranjeevi, P.; Kumar, A. V.; Sarasija, M.; Krishna, V. S.; Sriram, D.; Balasubramanian, S. RSC Adv. 2018, 8, 16997-17007. doi:10.1039/C8RA03197E

33. Thomas, J.; John, J.; Parekh, N.; Dehaen, W. Angew. Chem., Int. Ed. 2014, 53, 10155-10159. doi:10.1002/anie.201403453

34. John, J.; Thomas, J.; Parekh, N.; Dehaen, W. Eur. J. Org. Chem. 2015, 4922-4930. doi:10.1002/ejoc.201500459

35. John, J.; Thomas, J.; Dehaen, W. Chem. Commun. 2015, 51, 10797-10806. doi:10.1039/C5CC02319J

36. Thomas, J.; Jana, S.; John, J.; Liekens, S.; Dehaen, W. Chem. Commun. 2016, 52, 2885-2888. doi:10.1039/C5CC08347H 
37. Thomas, J.; Goyvaerts, V.; Liekens, S.; Dehaen, W. Chem. - Eur. J. 2016, 22, 9966-9970. doi:10.1002/chem.201601928

38. Jana, S.; Thomas, J.; Dehaen, W. J. Org. Chem. 2016, 81, 12426-12432. doi:10.1021/acs.joc.6b02607

39. Opsomer, T.; Thomas, J.; Dehaen, W. Synthesis 2017, 49, 4191-4198. doi:10.1055/s-0036-1588856

40. Vroemans, R.; Bamba, F.; Winters, J.; Thomas, J.; Jacobs, J.; Van Meervelt, L.; John, J.; Dehaen, W. Beilstein J. Org. Chem. 2018, 14, 626-633. doi:10.3762/bjoc.14.49

41. Silveira-Dorta, G.; Jana, S.; Borkova, L.; Thomas, J.; Dehaen, W. Org. Biomol. Chem. 2018, 16, 3168-3176. doi:10.1039/C8ОВ00533H

42. Jalani, H. B.; Karagöz, A. Ç.; Tsogoeva, S. B. Synthesis 2017, 49, 29-41. doi:10.1055/s-0036-1588904

43. Liu, S.-X.; Jia, C.-M.; Yao, B.-Y.; Chen, X.-L.; Zhang, Q. Synthesis 2016, 48, 407-412. doi:10.1055/s-0035-1560964

44. Gangaprasad, D.; Raj, J. P.; Kiranmye, T.; Karthikeyan, K.; Elangovan, J. Eur. J. Org. Chem. 2016, 5642-5646. doi:10.1002/ejoc.201601121

45. Heinrich, T.; Böttcher, H.; Gericke, R.; Bartoszyk, G. D.; Anzali, S.; Seyfried, C. A.; Greiner, H. E.; van Amsterdam, C. J. Med. Chem. 2004, 47, 4684-4692. doi:10.1021/jm040793q

46. Heinrich, T.; Böttcher, H.; Schiemann, K.; Hölzemann, G.; Schwarz, M.; Bartoszyk, G. D.; van Amsterdam, C.; Greiner, H. E.; Seyfried, C. A. Bioorg. Med. Chem. 2004, 12, 4943-4952. doi:10.1016/j.bmc.2004.07.014

47. Copmans, D.; Orellana-Paucar, A. M.; Steurs, G.; Zhang, Y.; Ny, A.; Foubert, K.; Exarchou, V.; Siekierska, A.; Kim, Y.; De Borggraeve, W.; Dehaen, W.; Pieters, L.; de Witte, P. A. M. Neurochem. Int. 2018, 112, 124-133. doi:10.1016/j.neuint.2017.11.011

48. Das, S. G.; Doshi, J. M.; Tian, D.; Addo, S. N.; Srinivasan, B.; Hermanson, D. L.; Xing, C. J. Med. Chem. 2009, 52, 5937-5949. doi:10.1021/jm9005059

49. Das, S. G.; Srinivasan, B.; Hermanson, D. L.; Bleeker, N. P.; Doshi, J. M.; Tang, R.; Beck, W. T.; Xing, C. J. Med. Chem. 2011, 54, 5937-5948. doi:10.1021/jm200764t

50. Ellis, G. P. In The Chemistry of Heterocyclic Compounds, Synthesis of Fused Heterocycles; Taylor, E. C., Ed.; John Wiley \& Sons Ltd., 1987; Vol. 47. doi:10.1002/9780470187302

51. Zhu, J.; Bienaymé, H. Multicomponent Reactions; Wiley-VCH: Weinheim, Germany, 2005. doi:10.1002/3527605118

52. Brauch, S.; van Berkel, S. S.; Westermann, B. Chem. Soc. Rev. 2013, 42, 4948-4962. doi:10.1039/c3cs35505e

53. Váradi, A.; Palmer, T. C.; Dardashti, R. N.; Majumdar, S. Molecules 2016, 21, 19-40. doi:10.3390/molecules21010019

\section{License and Terms}

This is an Open Access article under the terms of the Creative Commons Attribution License (http://creativecommons.org/licenses/by/4.0). Please note that the reuse, redistribution and reproduction in particular requires that the authors and source are credited.

The license is subject to the Beilstein Journal of Organic Chemistry terms and conditions: (https://www.beilstein-journals.org/bjoc)

The definitive version of this article is the electronic one which can be found at:

doi:10.3762/bjoc. 14.246 